\title{
Implementation of ICT tools to improve the object-oriented distance education in India: A perspective
}

Gudapati Naresh Raghava* and Darbha V Ravi Kumar ${ }^{\text {b\# }}$

${ }^{a}$ Department of Physics (Sciences), Amrita Vishwa Vidyapeetham, Chennai, India;

${ }^{b}$ Department of Chemistry (Sciences), Amrita Vishwa Vidyapeetham, Chennai, India

*Dr. G Naresh Raghava, Amrita Vishwa Vidyapeetham, Vengal, Chennai, 601103,

Email: g_nareshraghava@ch.amrita.edu

\#Dr. D V Ravi Kumar, Amrita Vishwa Vidyapeetham, Vengal, Chennai, 601103, Email:vrk_darbha@ch.amrita.edu 


\section{Implementation of ICT tools to improve the object-oriented distance education in India: A perspective}

India, being a country with a majority youth population, has a good opportunity to strengthen its economy in the next few decades. However, this could only be possible, if the youth population is trained with the required skill-set for the job market with improved opportunities for higher education. Unfortunately, the percentage of higher education enrolment does not possess encouraging numbers due to various social \& economic reasons. The ratio in the coming years can be improved by offering the higher education courses in open \& distance learning mode (ODL). Recently University Grants Commission (UGC also eased the norms for the higher educational institutes to offer ODL programs. However, the present ODL programs that are being offered were challenged with (i) lack of quality checks (ii) lack of paradigm shift in the course delivery, which is still through correspondence mode (iii) the degrees offered by the distance mode are not on par with regular courses. In this view, it is time to assess the quality of the present ODL programs and the necessary steps have to be initiated to improve the quality of the program. Due to the COVID 19 pandemic condition, major parts of the world dependent on online classes for the delivery of the regular courses, in this view, various tools for delivery and assessment are being widely used/developed. The integration of these tools with the present corresponding courses shall improve the quality of the courses. Herein, we comprehensively present the above-mentioned problems and solutions to improve the quality of ODL courses in India.

Keywords: open \& distance learning (ODL) in India; GER; ICT; peer assessment; Quality of open and distance education

\section{Introduction}

India is having the largest youth population in the world (Mitra \& Verick, 2013). The future of a country will be decided by how it utilizes this demographic dividend. By providing good quality education \& skills to its youth it can take the advantage of this 
demographic dividend and can become a major economic power house. Also, this will minimize social inequalities in the diverse country with inclusive development.

A large workforce is entering the job market every year in India. Many employers are complaining about the lack of skills in the youth for $21^{\text {st }}$ century jobs $(\mathrm{GBC} \&$ Education, 2019; India Skills, 2019). To have a positive correlation between education and employment opportunities, we should increase the quality of the education and skills provided to the youth of the country to have a sustainable livelihood. Higher education imparts such a kind of sustainable livelihood and makes the country a knowledge economy.

Students joining higher education in the country have increased considerably in the last two decades but still, students entering into higher education from the secondary schools are low. Though the enrolment in the primary education sector is almost a hundred percent, but only $1 / 4$ of these students are entering higher education in India (AISHE, 2019). There are various reasons for the low enrolment percentage for higher education in the country like economic affordability, and accessibility for the low Gross enrolment ratio (GER) in higher education (UGC, 2008). The number of students enrolled in the undergraduate courses is close to $80 \%$ whereas students enrolled in the postgraduate courses is around $10 \%$. The percentage of enrolment in higher education (category-wise) is depicted in Figure 1 (AISHE, 2019). On the other hand, the National educational policy, 2020 targets to achieve 50\% of GER in higher education by 2035 (NEP, 2020). To achieve this target, Open and Distance education (ODL) will play an important role \& also in imparting high-quality education and skills to the youth of the country. 


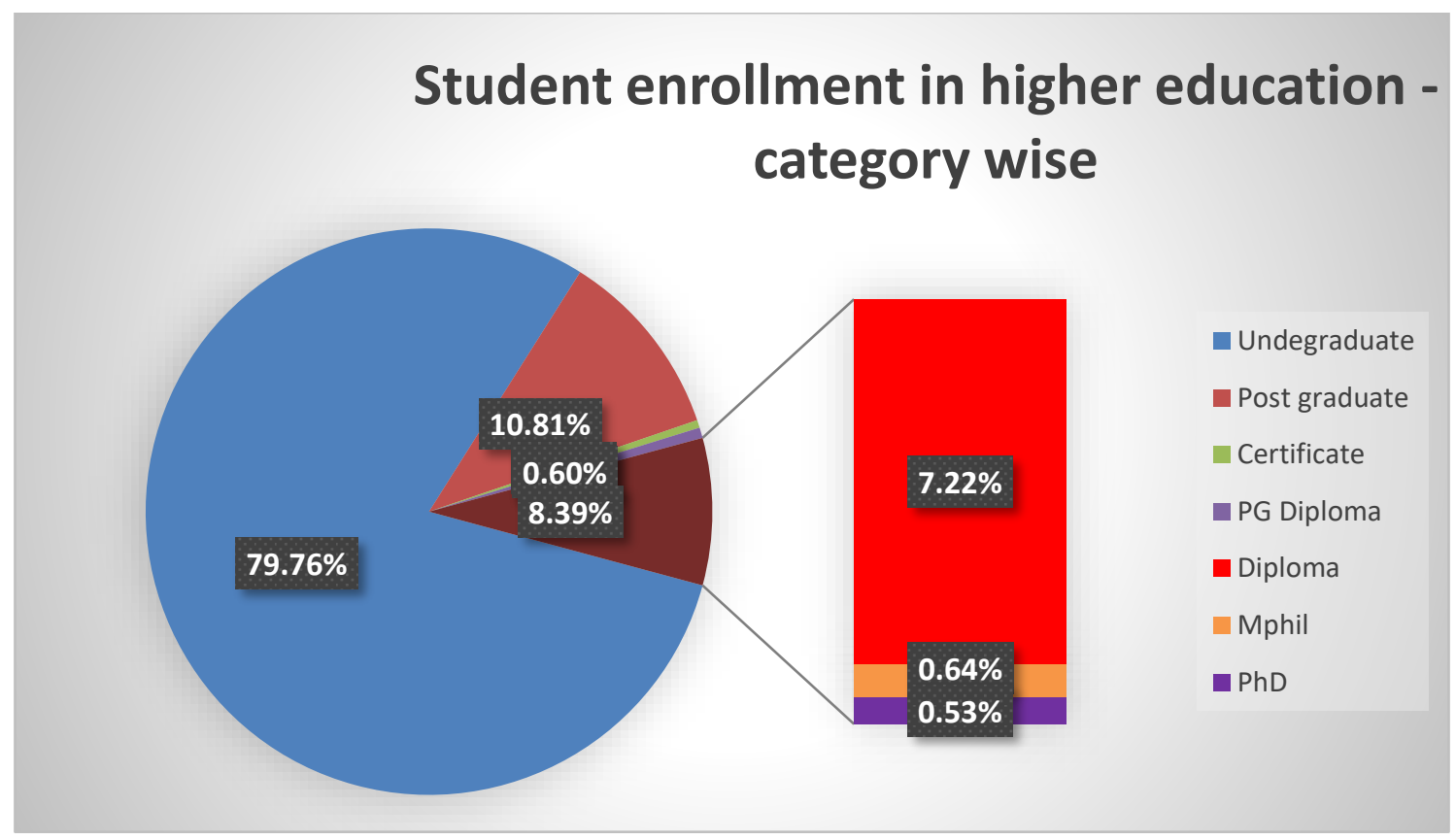

Figure 1

The contribution of Open \& distance learning (ODL) in higher education in some of the countries are shown in figure 2 (Qayyum \& Zawacki-Richter, 2019). In India, the share of distance enrolment constitutes $10.62 \%$ of total enrolment in higher education of which $44.12 \%$ are female. At Post Graduate, Undergraduate, PG Diploma, Diploma, Certificate level share of distance enrolment in university is $28.8 \%, 77.8 \%, 2.9 \%, 3.7 \%$, and $1.23 \%$ respectively (AISHE, 2019). For more students to enrol in higher education, ODL is going to play a crucial role as it also gives flexibility to learners in terms of choice, time, place, etc. For instance, learners can study at their own pace based on their convenience. This is helpful to learn the new skills for the workforce who left regular studies without leaving their jobs. ODL also gives the advantage that learners can study synchronously \& asynchronously. Still a large number of students in India are living away from higher educational institutions. So ODL is a boon for those students to access higher education and acquire the latest skills. Also, ODL is affordable to the vast population. 


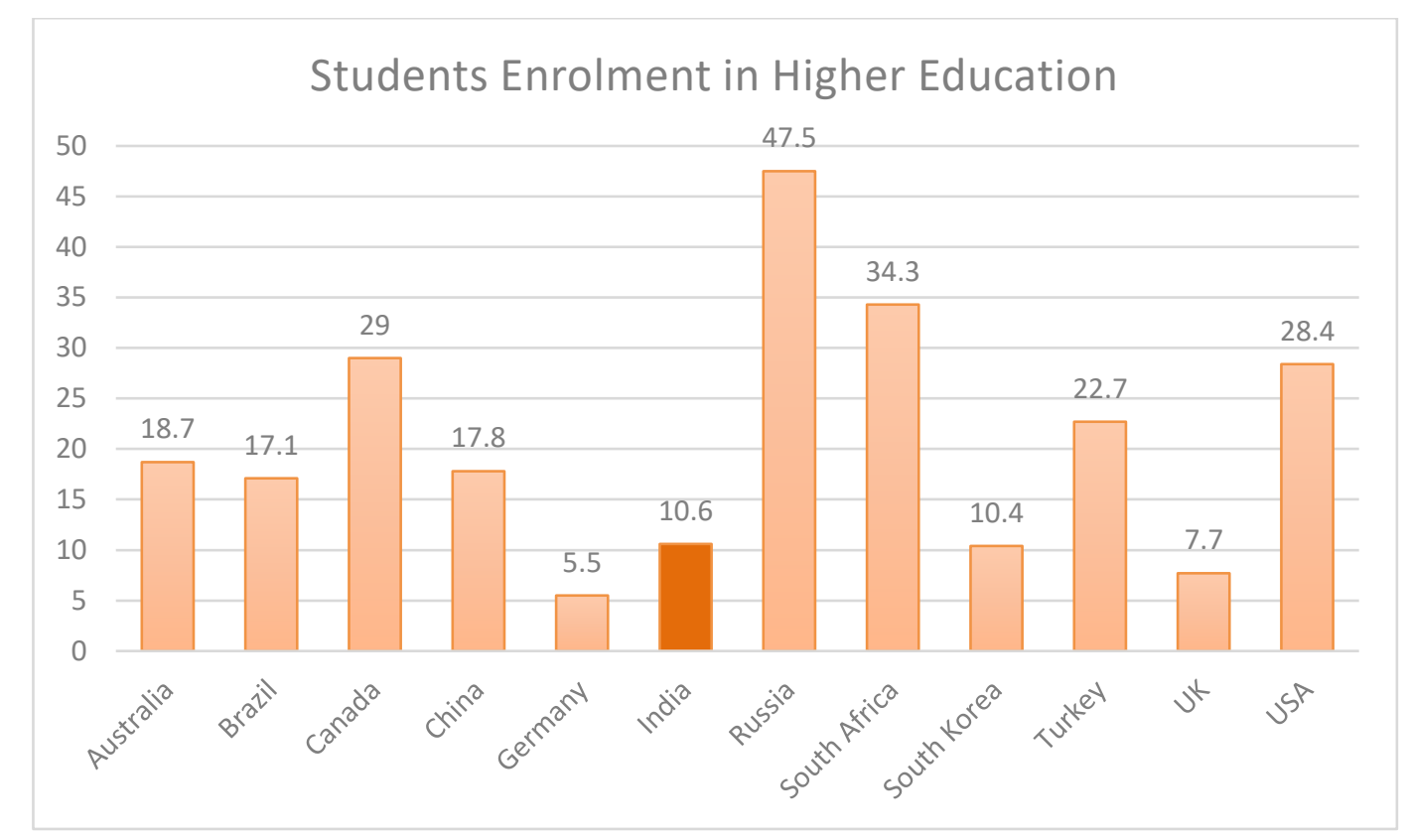

Figure 2

From the above discussion, it can be realized that ODL is instrumental to improve the enrolment in higher education and it is an excellent opportunity to improve the new technical/soft skills, hence it is important to revisit and revise open \& distance higher education in India and to have a look at how the quality of ODL can be improved on par with regular courses using ICT tools.

\section{Distance Education Scenario in India}

In the year 1962, Delhi university started a correspondence course, the first of its kind in India, as a pilot project. With the promising results shown by the pilot project and after studying the impact created by correspondence courses in the countries like USA, UK, USSR, and Japan, the National education commission which is also known as the Kothari Commission recommended the introduction of correspondence courses (Kothari et al., 1967). Subsequently, the government of India issued a resolution accepting the recommendation of the commission for the introduction of correspondence courses on a large scale at the University stage and such courses should be given the same status as 
full-time education. It further mentioned that such kind of correspondence courses will "promote the cause of education and provide opportunities to the large number of people who have the desire to educate themselves further but cannot do so on a full-time basis" (NEP, 1968). Over the years there were subsequent changes in the acts \& organizational bodies in administering the distance education system in India. In 2020, University Grants Commission has eased norms for higher educational institutions to offer ODL programs. Those institutions which secured a score of 3.26 in the National Assessment and Accreditation Council (NAAC) accreditation and have featured in the top 100 of the National Institutional Ranking Framework (NIRF) rankings for at least two years during the previous three years shall be permitted to start full-fledged open or ODL courses (NIRF, 2020).

\section{Issues currently faced by the distance education in India}

However, there are issues that are to be addressed to increase the quality of distance education in India. Distance education is still delivered mainly through the mode of correspondence while it is online in countries like Australia \& South Korea (Qayyum \& Zawacki-Richter, 2019). Moreover, these distance education courses became like an income source for the universities that are offering the courses and certificate earners for the candidates registering the course. At higher education level, the Government has taken several policies, independent bodies such as University Grants Commission (UGC), All India Council for Technical Education (AICTE), National Assessment and Accreditation Council (NAAC), National Board of Accreditation (NBA) to monitor the function of higher education institutions and to assure the quality education. Such initiatives were not employed to ensure the quality of distance education offered by several universities. Furthermore, these distance education courses lack proper assessment to evaluate the learning/course outcomes. As a result, the quality of the degrees that are earned by 
distance education has seen further downfall and currently, distance education degrees aren't on equal footing with residential degrees. And finally, the non-acceptability of these degrees in the job market has become a major concern (Gaba \& Li, 2015).

\section{The way ahead}

Distance educational institutions in India should emphasize changes to their delivery format in response to change in their demands. Usage of digital equipment for educational purposes has increased drastically in the past few years. The number of children who are enrolled in Indian schools owning a smartphone has increased from $36.5 \%$ in 2018 to $61.8 \%$ in 2020 (ESR, 2021). Online learning served as a panacea in the time of crisis. During the COVID-19 pandemic, we saw universities across the globe tied up with the MOOCs like Coursera, NPTEL, SWAYAM, Edx, and Great Learning to continue the quality learning and also developed E-content to their own courses, such content generated by various resources can be very well utilized to smoothen the teaching learning process of distance education course. In addition to this, distance education offering institutions must take the advantage of developments in information and communication technological (ICT) tools which are widely implemented in regular courses as a form of online classes due to COVID-19 pandemic. These institutions should use ICT tools \& online teaching to enhance the high-quality learning to the learners even though the correspondence mode is to be continued for some more time. These tools provide a "variety of materials that can be self-directed, cooperative, interactive, problemoriented, and flexible to prepare students for a digital world" (Zawacki-Richter, 2021).

\section{Learning Materials}

Online learning helps in making the student learning process more student-centric, more innovative, and even more flexible (Dhawan, 2020). As students can go through the 
lectures at any time, they appreciate the recorded lectures (Henderson et al., 2017). Distance educational institutions should offer recorded video lectures in their Learning management systems. At present study materials are offered to the student and they are predominantly in the printed form (Rao \& Delhi, 2020). This can also be offered in digital formats. Institutions offering distance education should make sure that materials should be accessible in mobiles to the learners as well (Basilaia, 2020 et al., 2020). In the study materials, Quick Response (QR) codes can be provided to access the interactive simulations or demonstrational videos (Law \& So, 2010; Lai et al., 2013). Such videos can be incorporated with formative assessment questions and offer feedback to ensure the engaging and interactive learning of the student (Susono \& Shimomura, 2006). This helps the learners to understand the concepts much better. Similar methodology can also be adopted to the courses that require experimental, programming and other laboratory based experimental skills using simulation/ virtual lab development software.

\section{Assessment}

Many distance education offering institutions evaluate assignments as part of summative assessment during the course but more weightage (around 70\%-80\%) is given for the end semester examination which is conducted at test centres. To enhance the learning outcomes formative assessments should be considered. Formative assessments can be conducted online in various formats like quizzes. A question pool can be created to conduct both formative and summative types of tests. Peer assessment and evaluation using ICT tools can be used to enhance the quality of online teaching and promote learning (Falchikov, 1986; Gaytan \& McEwen, 2007; Baldwin et al., 2018). Detailed feedback provided by the peer assessors is an important educational function (Falchikov, 1995; Ashenafi, 2017). 
Rubrics can be used to evaluate the student assignments. Rubrics can be useful to the learners to know the expected performance and clear grading criteria for the assignments (Roblyer \& Wiencke, 2003; Martin et al., 2019). Rubrics can also be shared with the peer assessors to give feedback. Also, discussion forums can be used for collaborative learning and timely response with currently available ICT tools/learning management systems (Martin et al., 2019).

The Universities which are going to be offering the distance-education shouldn't consider them as just a source of revenue. They should emphasize the quality of teaching $\&$ assessing the students. The assessments should measure their learning outcome and evaluate their technical skills, \& certificates earned by the learners should be both reliable \& valid across the globe.

ODL institutes generally offer degrees (undergraduate, postgraduate \& diploma) related programs in India. But they need not be restricted to such kinds of programs. These institutes can design \& offer certificate and industry related courses for those learners who want to gain new skill sets and to meet the requirements of local industries.

\section{Conclusion}

To summarize, the quality of the present ODL courses that presently lack equal footing with regular courses can be improved by integrating the ODL courses with ICT tools that were developed/improved/widely used in this pandemic. The recent tech revolution and the availability of smartphones with the average Indian citizen eases the above concept of integration of ICT tools with ODL courses. For example, recorded lectures and their accessibility can be provided to the student who is enrolled in ODL courses. The course material can be made more interactive by providing the material in a digital format with necessary QR codes to visualize the difficult concepts, interactive simulations, and demonstrational videos. Further, the assessment pattern can be changed by incorporating 
the formative assessment questions in the interacting reading/video materials. In addition to the existing summative assessment, weightage should be given to the formative assessment. To facilitate the proper assessment in the longer run, question pools can be created and peer-assessment should be encouraged with well-designed rubrics. The above suggested reforms could definitely improve the quality of distance education courses with measurable outcomes and these courses with improved delivery may train the young India and help them to improve their skills especially to the youth of rural India and who are unable to go for regular courses.

\section{References}

AISHE Report 2018-19, MHRD, Govt. of India (AISHE).

(2019). https://www.education.gov.in/sites/upload files/mhrd/files/statisticsnew/AISHE\%20Final\%20Report\%202018-19.pdf

Ashenafi, M. M. (2017). Peer-assessment in higher education-twenty-first century practices, challenges and the way forward. Assessment \& Evaluation in Higher Education, 42(2), 226251.

Baldwin, S., Ching, Y. H., \& Hsu, Y. C. (2018). Online course design in higher education: A review of national and statewide evaluation instruments. TechTrends, 62(1), 46-57.

Basilaia, G., Dgebuadze, M., Kantaria, M., \& Chokhonelidze, G. (2020). Replacing the classic learning form at universities as an immediate response to the COVID-19 virus infection in Georgia. Int. J. Res. Appl. Sci. Eng. Technol, 8(3), 101-108.

Dhawan, S. (2020). Online learning: A panacea in the time of COVID-19 crisis. Journal of Educational Technology Systems, 49(1), 5-22.

Economic survey report-2020-21 (ESR). (2021). https://www.indiabudget.gov.in/economicsurvey/doc/echapter vol2.pdf

Falchikov, N. (1986). Product comparisons and process benefits of collaborative peer group and self assessments. Assessment and Evaluation in Higher Education, 11(2), 146-166.

Falchikov, N. (1995). Peer feedback marking: Developing peer assessment. Innovations in Education and training International, 32(2), 175-187. 
Gaba, A., \& Li, W. (2015). Growth and development of distance education in India and China: a study on policy perspectives. Open Praxis, 7(4), 311-323.

Gaytan, J., \& McEwen, B. C. (2007). Effective online instructional and assessment strategies. The American Journal of Distance Education, 21(3), 117-132.

Global Business Coalition for Education and the Education Commission (GBC \&

Education). (2019). The 2030 Skills Scorecard Bridging business, education, and the future of work. https://gbc-education.org/wp-content/uploads/2019/09/GBC-Education-2030-Skills$\underline{\text { Scorecard.pdf }}$

Henderson, M., Selwyn, N., \& Aston, R. (2017). What works and why? Student perceptions of 'useful' digital technology in university teaching and learning. Studies in Higher Education, 42(8), 1567-1579.

India Skills Report 2019 (India Skills). (2019). https://www.aicteindia.org/sites/default/files/India\%20Skill\%20Report-2019.pdf

Kothari, D. S., Dawood, A. R., Elvin, H. L., Gopalaswami, R. A., Ihara, S., Jha, V. S., ... \& Mcdougall, J. F. (1967). Report of the education commission 1964-66: summary of recommendations. National Council of Educational Research and Training, New Delhi.

Lai, H. C., Chang, C. Y., Wen-Shiane, L., Fan, Y. L., \& Wu, Y. T. (2013). The implementation of mobile learning in outdoor education: Application of QR codes. British Journal of Educational Technology, 44(2), E57-E62.

Law, C. Y., \& So, S. (2010). QR codes in education. Journal of Educational Technology Development and Exchange (JETDE), 3(1), 7.

Martin, F., Ritzhaupt, A., Kumar, S., \& Budhrani, K. (2019). Award-winning faculty online teaching practices: Course design, assessment and evaluation, and facilitation. The Internet and Higher Education, 42, 34-43.

Mitra, A., \& Verick, S. (2013). Youth employment and unemployment: an Indian perspective. ILO.

National Education Policy 1968 (NEP). (1968). https://www.education.gov.in/sites/upload files/mhrd/files/document-reports/NPE-1968.pdf National Education Policy 2020 (NEP). (2020). https://www.education.gov.in/sites/upload files/mhrd/files/NEP Final English 0.pdf 
NIRF. (2020). https://www.ugc.ac.in/pdfnews/221580.pdf

Qayyum, A., \& Zawacki-Richter, O. (2019). The state of open and distance education. In Open and distance education in Asia, Africa and the Middle East (pp. 125-140). Springer, Singapore.

Rao, N., \& Delhi, N. (2020). Envisioning the future of open and distance learning system in India. Reimagining Indian Universities, 65.

Roblyer, M. D., \& Wiencke, W. R. (2003). Design and use of a rubric to assess and encourage interactive qualities in distance courses. The American journal of distance education, 17(2), 77-98.

Susono, H., \& Shimomura, T. (2006). Using mobile phones and QR codes for formative class assessment. Current developments in technology-assisted education, 2(2006), 1006-1010.

University Grants Commission (UGC). (2008). Higher education in India. Issues related to expansion, inclusiveness, quality and finance.

Zawacki-Richter, O. (2021). The current state and impact of Covid-19 on digital higher education in Germany. Human Behavior and Emerging Technologies, 3(1), 218-226. 